\title{
The performance of a glass bead shaking technique for the disruption of Escherichia coli cells
}

\begin{abstract}
The efficacy of a simple laboratory method for cell disruption based on the shaking of glass beads on a rotary shaker was assessed in this study, via measurements of the release of total protein and interferon- $\alpha 2 b$ from E.coli. The optimum conditions for cell disruption were detected after $30 \mathrm{~min}$ of shaking in Tris- $\mathrm{HCl}$ buffer $(\mathrm{pH} 8)$ at $300 \mathrm{rpm}$ with $1.5 \mathrm{~g}$ of glass beads (diameter: $0.5 \mathrm{~mm}$ ) per $\mathrm{mL}$ of cell suspension volume. Three test runs were conducted under the above conditions and the maximum average protein release values were determined as $3.048,3.564$, and $3.015 \mathrm{mg} / \mathrm{mL}$, respectively. The amount of protein release was comparable to the amount of protein release in ultrasonication and glass bead vortexing procedures. The amount of interferon- $\alpha 2 \mathrm{~b}$ release in the ultrasonication, glass bead vortexing, and glass bead shaking trials were 240,172 , and $201 \mathrm{ng} / \mathrm{mL}$, respectively. This method was shown to process between 1 and $10 \mathrm{~mL}$ of sample volume in a $50 \mathrm{~mL}$ Falcon tube without a great deal of deviation, and was able to handle in excess of 60 samples simultaneously.
\end{abstract}

Keyword: Cell disruption; Downstream processing; E.coli; Glass beads; Shaker; Interferona2b. 